\title{
THE "CASH SALE" PRESUMPTION IN BAD CHECK CASES: DOCTRINAL AND POLICY ANOMALY
}

SELLERS who accept worthless checks frequently seek to aroid the loss by recovering from third parties to whom the buyer has transferred the goods. Recovery depends on who is found to hold title to the merchandise. 1 While the intent of the parties governs title passage, ${ }^{2}$ sellers and buyers rarely express any clear intention. ${ }^{3}$ So courts are forced to presume the parties' intent.* The presumptions of intent contained in Section 19 of the Liniform Sales Act provide for title passage irrespective of payment. Yet numerous courts presume that a non-credit transaction ${ }^{5}$ (goods to be paid for on delivery)

1. Under the Uniform Sales Act, upon unconditional delivery, seller loses his lien, \$ 56 , his right to resell, $\$ 60$, and his power to rescind title passage, $\$ \$ 61,65$. Thus, unless seller retains a security interest, only "title" will permit him to recover the gcods.

The common law and statutory technique of resolving nearly every question in salcs law by resort to "title" has been severely criticized. See Llewellyn, Throwgh Tilic to Contract and a Bit Beyond, 15 N.Y.U.L.Q. Rev. 159, 165 (1938). The Uniform Commercial Code (Official Draft 1952) seeks to eliminate the pre-eminent importance of the title concept. See Latty, Sales and Title in the Profosed Code, 16 Liw \& Co:iress. Proв. 3 (1951). For a criticism of the Code's position and a defense of the title concegit, see Williston, The Law of Sales in the Proposed Uniform Conmercial Code, 63 Hans. L. REv. 561,568 (1950).

2. UNIFORr SAlEs Act $\$ 18$. The Act has been adopted by 35 states, Hawaii, and the District of Columbia. For cases in these and common law jurisdictions, sce 1 U:i1-

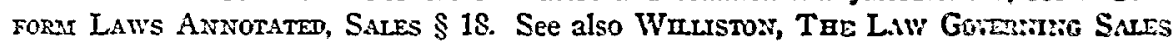
of Goons $\$ 261$ (2d ed. 1948) (hereinafter cited as WiruIsTox, SALES); Vold, HaribeCOK of the Law of Sales 122 (1931) (hercinafter cited as Vold, Sules).

3. This is particularly true in cases where the seller does not agree to doliver goids until he receives payment. He considers possession of the goods all the sceurity lte nceds, so there is generally no reason to provide specifically for title passage. See Note, 23 Kx. L.T. 322, 325 (1940).

4. UnIrorus SALEs ACT $\$ 19$. These presumptions, of course, do not necessarily reflect the parties" ("true") intention. See Latty, Salcs and Tille in the Profosed Code, 16 L.w \& Contexrp. Prob. 3, 12, 13 (1951). It has long been recognizcd that cuurts use presumptions of title passage to achieve what they consider to be sound commercial results. E.g., Holnsworth, A History of the English Law 355 (3d ed. 1927). See alco Nots, 4 ST. Jorn's L. REv. \$5, \$6 (1929).

5. For a "cash sale" ( see note 6 infra), absence of credit is essential. E.g., Weyerhaeuser Timber Co. v. First Nat. Eank, 150 Ore. 172, 43 P.2d 1078 (1935); Gustafson v. Equitable Loan Ass'n, 186 Minn. 236, 243 N.W. 106 (1932); John Sims \& Sons v. Eoltun, 138 Ga. 73, 74 S.E. 770 (1912). Whether a check alters the original non-credit charaeter of the transaction is, therefore, a crucial question. See notes 50 and 54 infra. A "cash sale" has accasionally been found where the buyer failed to surrender a note, c.g., Millhicer v. Erdman, 98 N.C. 292,3 S.E. 521 (1887); Coggill v. Hartford \& N.H.R.R., 3 Gray 545 (Miass. 1854), although in such cases credit has obviously been extended. See Vuld, Cash Sales, 14 ST. Lours L. REv. 1, S n.27 (1928). Whether the trancaction is fur credit depends on the parties' intention. And in the absence of express intention, cuurts generally presume the sale to be a non-credit transaction. E.g., Gustafson v. Equitable Loan Ass'n, supra. 
indicates that the parties intended a "cash sale" - payment to be a condition of title passage. ${ }^{7}$ No title passes to the buyer if he gives a worthless check to the seller, since a check is generally not deemed payment until honored. ${ }^{8}$ And under the axiom that one cannot pass better title than he himself holds, the buyer cannot transfer title to a third party. Some courts still permit seller recovery on this rationale ${ }^{10}$ despite the trend in modern bad check cases toward protection of bona fide third parties. ${ }^{11}$

On a conceptual level, the "cash sale" presumption defies justification. Under the Uniform Sales Act, a non-credit transaction by itself cannot raise a presumption of "cash sale." Section 42 of the Act presumes that, unless otherwise agreed, delivery of the goods and payment of the price are concurrent conditions. If an agreement, express or presumed, for payment on delivery is used as a basis for finding that the parties intended title to pass on payment, then Section 42 must necessarily lead to the same result. But such an interpretation of the Act is absurd: Section 19 prestumes that the parties intended title to pass irrespective of payment at the same time Section 42 would presume that the parties intended title to pass upon payment.12 The only reasonable interpretation of the two sections is that "payment on

6. "Cash sale" can be defined in three ways. (1) Payment, title passage, and delivery coincide. This is the definition used in this Note. See Llewliyn, Cases and Materuals on Sales 703 (1930); Williston, Sales $\$ 341$ et seq.; Vold, Cash Sales, 14 Str. Lours L. Rev. 1 (1928); Note, 4 St. John's L. Rev. 85 (1929). But see Tirfany, Sales 123, 268 (2d ed. 1908). (2) Payment is a condition of delivery only. (3) Payment is merely a condition of title passage. For the alternative definitions, see Notes, $28 \mathrm{KY}$. L.J. 322 (1940) ; 36 Dick. L. Rev. 276, 277 (1932).

7. E.g., Publicker Commercial Alcohol Co. v. Harger, 129 Conn. 655, 31 A.2d 27 (1943) ; De Vries v. Sig Ellingson \& Co., 100 F. Supp. 781 (D. Minn. 1951); Tyler v. Kelley Timber Products Co., 192 Ore. 368, 233 P.2d 774 (1951) ; Parker v. First Citizens Bank \& Trust Co., 299 N.C. 527, 50 S.E.2d 304 (1948). For a collection of cases, sce Williston, Sales § 346a n.14; Notes, 20 Chi. Kent. L. Rev. 182, 183 n.3 (1942) ; 28 Kx. L.J. 322, 323 n.11 (1940).

8. For cases, see Steffen, Cases on Commercial and Investasent Paper 116 (1939). This rule has been adopted in $\S 2-511(3)$ of the proposed Uniform Commercial Code (Official Draft 1952).

9. Uniform Sales Act § 23(1). See also Untforar Comsmerctal Code § 2-403(1) (Official Draft 1952). The axiom, traditional trap for bona fide third parties, fits into the pattern of a "caveat emptor" law of sales. See, generally, Hamilton, The Ancient Maxim Caveat Emptor, 40 YALE L.J. 1133 (1931).

10. See note 7 supra.

11. For the modern case law trend, see Notes, 13 Mo. L. REv. 211, 213 (1948); 20 Chi. Kent. L. Rev. 182, 187 (1942). See also cases cited in notes 39, 48, 49, 55 infra.

12. Yet a presumption for a "cash sale," because payment and delivery are simultancous, leads to this conclusion. Tyler v. Kelley Timber Products Co., 192 Ore. 368, 233 P.2d 774 (1951), involved a contract for the delivery of logs, payment to be made by clicek every two weeks. When the check for the last installment was dishonored, the seller brought an action for replevin against the assignee of the buyer's mortgagee. The court held that in the absence of an express agreement, $\$ 42$ provides for a "cash sale." Brushing off the two week period, the court found delivery and payment "substantially simultaneous." See note 50 infra. The seller was found to hold title and permitted to recover. In Turner 
delivery"-whether expressly agreed to or presumed-refers only to the time when the goods are to be transferred physically, while title passes under Section 19 regardless of payment. ${ }^{13}$ Nor can Section 19 be rebutted by contract clauses using the word "cash"-such as "Cash on Delivery" or "For Cash."1 Such clauses in commercial parlance have the same meaning as "Payment on Delivery." 15

Moreover, courts presuming a "cash sale" often ignore facts which seem to support the Section 19 presumptions. Section 19 presumes, for example, that when specific goods are sold, the parties intend title to pass before delivery or payment. ${ }^{16}$ How can one reasonably infer that the parties do not intend to pass title when the seller, immediately after contracting, delivers the goods and receives conditional payment in the form of a check? Yet a contract which contemplates immediate execution is often considered an earmark of a "cash sale."17 Certainly, an "intent" to transfer ownership seems far more likely when the seller delivers the goods and accepts a check than where there has been no delivery and no attempt to make payment. Furthermore, a "cash sale" presumption appears wholly unrealistic when a merchant is the buyer. ${ }^{18}$ Sellers who, in the ordinary course of business, transfer goods to a merchant, without any limit on his right to resell, must expect the buyer to sell as soon as a customer is found. Translated into doctrinal terms, the seller "intends" to transfer at least one element of title, the right to resell ;0 thus the buyer would receive actual authority to dispose of the goods.?

v. Benz Bros. \& Co., 153 Wash. 123, 279 Pac. 398 (1929), the court applied \& 19. But then referring to $\$ 42$, the court concluded that in the absence of an agreement to the contrary, no title passed to the buyer before payment. The seller recovered.

13. See Williston, Sales \$ 448; Vold, Cash Sales, 14 St. Lours L. Rev. 1 (1923).

14. E.g., Goddard Grocer Co. v. Freedman, 127 S.W.2d 759 (Mo. 1939) ("cash price") ; Weyerhaeuser Timber Co. v. First National Bank, 150 Ore. 172, 43 P.2d 1073 (1935) (terms 98\% cash) ; Cass County Bank v. Hulen, 195 S.W. 74 (Mfo. 1917) ("cash on delivery"). See also Notes, 24 GEo. L.J. 172 (1935); 17 Tem. L. Rev. 272, 273 (1942).

15. South San Francisco Packing \& Provision Co. v. Jacobsen, 183 Cal. 131, 190 Pac. 628 (1920) ; Kinney v. Horwitz, 93 Conn. 211, 105 Atl. 438 (1919); Gillingham v. Phelps, 5 Wash. 2d 410, 105 P.2d $\$ 25$ (1940). See also Williston, S.ires $\$ 343$; Note, 4 Sr. JoHN's L. REv. $\$ 5$ (1929).

16. $\S 19$, Rule 1 .

17. E.g., Wirliston, Sales $\$ 343$; Vold, Cash Sales, 14 St. Louis L. Rev. 1, 3 (1928).

18. E.g., Peerless Motor Co. v. Sterling Finance Corp., 139 Cal. App. 621,34 P.24 738 (1934) ; Boyd v. Bank of Mfercer Co., 174 MIo. App. 431, 160 S.IW. 557 (1913); Keegan v. Lenzie, 171 Ore. 194, 135 P.2d 717 (1943); John S. Hale \& Co. v. Beley Cotton Co., 154 Tenn. 689, 290 S.W. 944 (1927).

19. "If the principal sends his commodity to a place, where it is the ordinary business of the person to whom it is confided to sell, it must be infended that the commodity was sent thither for the purpose of sale." Lord Ellenborough in Pickering v. Buck, 15 East 38 , 43 (1812) (emphasis added). For a criticism of the decision, see Wulusto:i, Sales $\S 314$.

20. See Vold, Cash Sales, 14 ST. Lours L. Rev. 1, 9 (1923). (f. Kearby v. Western States Securities Co., 31 Ariz. 104, 250 Pac. 766 (1926). 
The weakness of the "cash sale" doctrine is most obvious in the way courts manipulate presumptions of the parties' intent ${ }^{21}$ according to the nature of the claim. For example, in actions for the price, courts generally hold that title passes according to the Section 19 presumptions. ${ }^{22}$ However, when the seller who accepted a bad check sues a third party to recover goods, courts ignore Section 19 and presume that the parties intended title to pass at the time of payment, ${ }^{23}$ despite a contract nearly identical with those in successful price actions. ${ }^{24}$ In short, seller recovers in the price action

21. For various imaginative speculations about the "true" intentions of the parties, see, e.g., Williston, Sales $\$ 346 \mathrm{a}$; Collins, Title to Goods Paid For zeith Worthless Check, 15 So. Car. L. Rev. 340, 342 (1942); Notes, 13 Mo. L. REv. 211, 212 (1948) ; 34 IowA L. Rev. 371, 372 (1949); 13 ORE. L. Rev. 177, 178 (1934).

22. See cases cited in 1A Uniform Laws Annotated, Sales $\$ 63$ n.32. See also note 24 infra.

23. See cases cited notes 7 supra and 24 infra.

24. E.g., Alabanra: Compare Barksdale v. Banks, 206 Ala. 569, 90 So. 913 (1921) (sale of mules; express clause for payment by cash; payment made by bad check; seller recovers mules from bona fide purchaser), with Iron City Grain Co. v. Arnold, 215 Ala. 543, 112 So. 123 (1927) (hay sold by the ton, immediate delivery and payment contemplated by parties; hay delivered and price ascertained but hay destroyed by fire before payment; seller recovers price); Californin: Compare South San Francisco Packing \& Provision Co. v. Jacobsen, 183 Cal. 131, 190 Pac. 628 (1920) (sale of hogs, payment to be made by check upon delivery; goods delivered and buyer's check dishonored; seller recovers hogs from buyer's creditors), with Browning v. McNear, 158 Cal. 525, 111 Pac. 541 (1910) (sale of grain, to be paid for when shipped; goods destroyed before payment; seller recovers price); ConNecticut: Compare Publicker Commerical Alcohol Co. v. Harger, 129 Conn. 655, 31 A.2d 27 (1943) (sale of alcohol in installments, payment to be made by checks which buyer had signed and left with seller; checks to be filled out at each delivery; check dishonored after delivery of installment; seller recovers alcohol from bona fide third parties), with Kinney v. Horwitz, 93 Conn. 211, 105 Atl. 438 (1919) (sale of potatoes, payment to be made when bill of lading delivered; bill drawn in name of seller and not delivered to buyer; potatoes destroyed by fire; seller recovers price); MINNESOTA: Compare Gustafson v. Equitable Loan Ass'n, 186 Minn. 236, 243 N.W. 106 (1932) (goods delivered for check; check dishonored; seller recovers goods from third party), with Mobile Fruit \& Trading Co. v. McGuire, 81 Minn. 232, 83 N.W. 833 (1900) (sale of bananas, pay ment presumably to be made on delivery ; goods deteriorated before delivery; seller recovers price); MissourI: Compare Lewis v. James MrMahon \& Co., 307 Mo. 552, 271 S.W. 779 (1925) (sale of oil, check payment when bill of lading delivered; check dishonored; seller held to have retained title and third party not bona fide so oil recovered), zeith Williams v. Evans' Adm'r, 39 Mo. 201 (1866) (sale of goods with payment to be made on delivery; buyer held to have received title and thus risk of loss on him); NEw JenseY: Compare Morehouse v. Keyport Auto Sales Co., 118 N.J. Eq. 368, 179 Atl. 279 (1935) (sale of car, payment by check on delivery; check dishonored; seller permitted to recover car from buyer's creditors because parties intended title to pass on payment), with Lummis v. Millville Mfg. Co., 72 N.J.L. 25, 60 A.2d 19 (1905) (sale of grain, payment to be made against delivery; seller received check, but buyer stopped payment when schooner carrying grain sank; held seller recovers price because title had passed to buyer); Онго: Compare Rehr v. Trumbull Lumber Co., 110 Ohio St. Rep. 208, 143 N.E. 558 (1924) (timber sold f.o.b., payment to be made on delivery, part in cash, part by note; seller recovers goods from buyer's receiver), with Newhall v. Langdon, 39 Ohio 
because title passed to the buyer while he wins his action to recover goods because the court finds he has retained title-contradictory theories. The paradox can be explained only by the policies courts are seeking to implement. Historically, courts have followed a policy of shifting the risk of destruction of goods to the buyer as soon as possible.25 Since this risl: of loss follows title, ${ }^{26}$ early title passage must be found in price actions. Apparently, courts have also sought to protect sellers against losses from non-payment; so courts are inclined to find title in the unpaid seller when he sues to recover goods. To accomplish both policies, the doctrinal inconsistency was inevitable. $^{27}$ But seller recovery of goods from bona fide third parties is no longer supported by sound commercial policy.

Some courts and commentators have suggested that the "cash sale" doctrine safeguards transferability of goods; $;$ if if recovery from third parties were denied, sellers would be reluctant to exchange goods for checks and require, instead, the more burdensome cash payment. ${ }^{29}$ An equally speculative argument, however, could justify rejection of the "cash sale" presumption." Third party liability might delay sales until prospective purchasers could ascertain the details of prior transactions. Purchaser caution should impede transferability as much as seller reluctance to accept checks. Moreover, the threat of bad check losses should not necessarily outweigh the seller's interest in the speed and convenience of check transactions. ${ }^{31}$

Relatively simple precautions would enable sellers to prevent bad check losses in most cases. Sellers can call or wire the buyer's bank to learn whether sufficient funds are on deposit. ${ }^{32}$ Such practices would have revealed the

St. Rep. 87, 48 Am. Rep. 426 (1883) (sale of flour, payment to be made on delivery; flour destroyed before delivery or payment; seller recovers price); Wasunicton: Comparc Quality Shingle Co. v. Old Oregon Lumber \& Shingle Co., 110 Wash. C0, 187 Pac. 705 (1920) (sale of ascertained shingles, check payment to be made on delivery of bill of lading; check dishonored; bill of lading held non-negotiable; seller recovers proceeds from sale of goods from third party), with Izett v. Stetson \& Post Míll Co., 22 Wash. 300,60 Pac. 112s (1900) (logs sold with payment deferred until sealing; without sealing or payment, logs delivered to buyer; seller recovers price).

25. See Gilmore, Chattcl Secatrity, 57 YaLE L.J. 517, 523 (1948).

26. Uniforar Sales ACT $\$ 22$. The same rule existed under common law. WhLISTON, SALES $\S 301$.

27. For a criticism of "title" as the solution of nearly all problems in the law of sales, see sources cited note 1 supra.

28. See Young v. Harris-Cortner Co., 152 Tenn. 15, 26S S.W. 125 (1924). For a diseussion of this argument, see Voln, Sales 175, 176; Vold, Worthless Chcel: Cash Salcs, "Substantially Simultaneous" and Conficting Analogics, 1 HAstrugs Jounsul 111, 127 n.42; Ballantine, Purchase for Value and Estoppel, 6 Mrmi. L. Rev. 86, 120 et scq. (1922); Note, 28 Ky. L.J. 322, 326 (1940).

29. See Young v. Harris-Cortner Co., 152 Tenn. 15, 25, 268 S.W. 125, 127 (1924).

30. See Cowan v. Thompson, 25 Tenn. App. 130, 152 S.W.2d 1036 (1941); Note, $28 \mathrm{Kr}$. L. J. 322, 326 (1940).

31. Ibid.

32. Banks generally disclose to anyone whether a check for a specified amount would be covered by the account. On the other hand, they do not give information relating to 
worthlessness of buyer's check in almost all the reported cases. ${ }^{33}$ While speedy communication devices were unavailable when common law courts developed the "cash sale" doctrine, today such inquiries are feasible. But a call or wire does not preclude all risks: the buyer's signature may be forged ${ }^{34}$ or the funds may be withdrawn or exhausted after the seller's inquiry. ${ }^{35}$ These risks, however, may be minimized. The seller can withhold delivery until the check is cleared. Or certification, though admittedly impractical for most transactions, may be demanded when valuable goods are sold. Finally, the seller can always refuse to accept the buyer's check if he has cause to be suspicious. ${ }^{36}$

On the other hand, a third party can prevent the loss only by tracing title every time he intends to acquire goods. To succeed, the third party would have to determine whether: the prior parties intended payment to be a condition of title passage; payment in any preceding transaction had been made by check; the check had been honored or the seller had been paid another way. Clearly, it would be completely impractical to require such diligence of prospective third parties. And judicial standards of good faith have never demanded these efforts unless special facts forewarned the third party. $^{37}$

the amount on deposit unless the other party has identified himself as the the owner or shows some other authorization. See Country Banks Operation Conm., Aruerrcan Bankers Ass'n, Bank Tellers Do's and Don't's 2 (March 1952). Under these circumstances the seller could obtain sufficient information before he surrenders possession of the goods in the great majority of the check transactions. He can, of course, always discover whether the other party has an account with the named bank.

33. In 119 of 126 bad check cases examined, the reported facts show no inquiry by the seller. Yet in almost the same number of cases the facts suggest that no account existed or insufficient funds were on deposit when the seller accepted the check.

34. See, e.g., Dudley v. Lovins, $310 \mathrm{Ky} .491,220$ S.W.2d 978 (1949). In forgery cases, the potential buyer is probably a stranger. Sellers should always exercise greater care when dealing with strangers. And if the buyer presents a check in the name of a firm, the seller should ascertain from the firm the buyer's authority. Where the buyer passes a check with a forged certification, the seller's inquiry at the bank would disclose the fraud. See Goddard Grocer Co. v. Freedman, 127 S.W.2d 759 (Mo. 1939).

35. No case has been found where the buyer withdrew his funds after delivery of the check in order to defraud the seller. There are cases, however, where the buyer's account would have covered the check sometime between its surrender and its presentation. E.g., South San Francisco Packing \& Provision Co. v. Jacobsen, 183 Cal. 131, 190 Pac.628 (1920); Crescent Chevrolet Co. v. Lewis, 230 Iowa 1074, 300 N.W. 260 (1941). No fraud was found in either case.

36. Sellers are generally not obliged to accept a check instead of cash payment. E.y., Karetnick v. Skriloff, 8 N.J. Misc. 671, 151 Atl. 386 (1930). But cf. Lee v. Hendrickson, $303 \mathrm{Ky} .39,196$ S.W.2d 880 (1946) (certified check held valid tender of payment). Under the proposed Uniform Commercial Code, the seller, although under no obligation to accept anything but legal tender, is required to extend reasonably the period of pay. ment if he rejects tender which is made "by any means or in any manner current in the ordinary course of business." Uniform Commercial Code $\S 2-511$ (2) (Official Draft 1952).

37. E.g., Goddard Grocer Co. v. Freedman, 127 S.W.2d 759 (Mo. 1939). 
A rule holding sellers liable would probably distribute bad check losses more equitably. If seller and third party are both merchants or both consumers, one cannot generalize that either is likely to be a better risk bearer. ${ }^{35}$ If merchants, both may be able to include the loss in the cost of business operations; if consumers, neither can do so. Since merchants constantly alternate between seller and purchaser roles, they would not benefit or suffer from either seller or third party liability for bad check losses. But consumers are typically ultimate purchasers, seldom sellers. In almost every bad cheek case involving a consumer, therefore, he will be the third party and the "cash sale" doctrine would shift the loss to him, the party probably less able to bear it. In sum, seller liability for worthless checks would place the loss on the party who is both better able to prevent it and more often the better risk bearer.

To further third party protection, courts should adhere to the Section 19 presumptions of title passage. ${ }^{39}$ Only a clearly expressed intent to the cuntrary, not a "Cash on Delivery" clause, should rebut Section 19.20 In jurisdictions that adopt the proposed Uniform Commercial Code, all purchasers in the ordinary course of business will be protected regardless of title notions. ${ }^{41}$ For other third parties, however, title remains significant. 32 The Code requires an explicit agreement to pass title at the time of payment 43 and expressly says a "Cash Sale" clause, by itself, would not qualify:" Even strict adherence to Section 19 or the proposed Code would permit sellers and buyers to contract for title passage upon payment. ${ }^{26}$ So sellers may continue

38. But see Note, $28 \mathrm{KY}$. L.J. 322, 326 (1940), where it is suggested that the soller should bear the loss in bad check cases because he profits from the increased turnover of goods.

39. Section 19 of the Uniform Sales Act was designed to codify the cominun law of title passage. Wrisiston, Sales $\$ 264$. It could be argucd that since the contradictory presumptions of title passage, see note 24 supra, were applicd bsfore adoytion of the Act, $\$ 19$ was not intended to alter the presumptions used in unpaid sellers' actions to recover goods. However, as a matter of statutory interpretation, $\$ 19$ on its face wuuld cover the typical "cash sale" case.

If title is held to have passed under $\$ 19$, the seller could still recover the gosds from the buyer if the check was fraudulently offercd as fayment, since the buyer's title would be "voidable." Cf. Island Trading Co. v. Berg Bros., Inc, 239 N.Y. 229, 146 N.E. 345 (1924); Petty v. Borg, 106 Utah 524, 150 P.2d 776 (1944). Or the seller may be found to have reserved his right of possession as against the buyer. U:rFusus Sales Act $\$ 20$. However, a voidable title would become indefeasible if transferred to a bona fide buyer. Id. § 24. E.g., Dudley v. Lovins, $310 \mathrm{Ky} .491,220$ S.W.2d 978 (1949); Farr v. Helfrich, 108 Neb. S01, 189 N.W. 281 (1922); Ross v. Leuci, s5 N.Y.S.2d 497 (1949). Ci. Crescent Chevrolet Co. v. Lewis, 230 Iowa 1074, 300 N.W. 200 (1941).

40. Seee Note, 36 Dick. L. REv. 276, 282 (1932).

41. Uniforar Comimerctal Code $\$ 2-403$ (Official Draft 1952).

42. Id. $\S 2-401$.

43. Id. $\$ 2-401$ (1).

44. Id. $\$ 2-401$ (1) (b).

45. Courts could not reasonably avoid finding a cash sale if the seller expresses an intent not to transfer title when he receives the check. E.g., Turner v. Benz Bros. \& Co., 
to use the "cash sale" rationale to seek recovery from some third parties. Other doctrines would be needed to block such attempts.

Some writers have urged that the seller who surrenders goods in exchange for a check should be presumed to have waived his right to retain title. ${ }^{40}$ The presumption of waiver, however, makes little sense if a court initially finds a "cash sale." At the very time a court determines that the parties intended no title passage, the court is asked to presume seller's waiver of title retention. ${ }^{47}$ While the waiver defense has rarely been applied, ${ }^{48}$ a few courts have protected third parties on a conditional sale or chattel mortgage rationale $:^{40}$ the "cash sale" seller, like the conditional seller, is extending credit to

153 Wash. 123, 279 Pac. 398 (1929) ("the hay is mine until it is paid for"). Or where the seller purposely does not transfer a bill of sale to the buyer. E.g., Alonso v. Badger, 58 Cal. App. 2d 752, 138 P.2d 24 (1943). Car sellers frequently retain the ccrtificate of title to ensure payment of the check. E.g., Kirk v. Madsen, 240 Iowa 532, 36 N.W.2d 757 (1949).

46. This approach has been suggested by Wiruiston, SAles $\$ \S 346 \mathrm{a}, 346 \mathrm{~b}$, and has been adopted by Collins, Tille to Goods Paid For by Worthless Check, 15 So. Culfr. L. Rev. 340 (1942), and in Note, 28 KY. L.J. 322 (1940). See also Comment, 34 Iows L. Rev. 371 (1948).

47. For a criticism of the waiver approach, see Vold, Worthless Check Cash Salcs, "Substantially Simnltaneous" and Conflicting Analogies, 1 Hastings Journat 111, 114, 115 (1950).

48. Veblen v. Foss, 32 Wash. 2d 385, 201 P.2d 719 (1949). Cf. United States v. Lutz, 142 F.2d 985 (3d Cir. 1944); Weyerhaeuser Timber Co. v. First National Bank, 150 Ore. 172,43 P.2d 1078 (1935).

49. Georgia is the only jurisdiction in which a conditional sale statute seems to be regularly applied in bad check cases. E.g., Hall v. Le Croy, 79 Ga. App. 676, 54 S.E.2d 468 (1949) ; Capital Automobile Co. v. Ward, 54 Ga. App. 873, 189 S.E. 713 (1936); Brumby Chair Co. v. City of Columbus, 46 Ga. App. 163, 167 S.E. 221 (1932). The chattel mortgage approach has recently been used in Pettus v. Powers, 185 S.W.2d 872 (Kan. 1945). An attempt to introduce the rationale in Iowa was apparently unsuccessful. Compare Morse v. Chicago, R.I. \& P.R.R., 73 Iowa 226, 34 N.W. 825 (1887), with Crescent Chevrolet Co. v. Lewis, 230 Iowa 1074, 300 N.W. 260 (1941). Some courts and commentators have rejected the recording approach. Morehouse v. Keyport Auto Sales Co., 118 N.J. Eq. 368, 179 Atl. 279 (1935); Johnson Brinkman Comm. Co. v. Central Bank, 116 Mo. 558, 22 S.W. 813 (1893). See also Comment, 13 Mo. L. Rev. 211, 216 (1948). The crux of the dispute is whether or not the seller can be considered to have extended credit. See notes 50, 54 infra. For a general discussion of the conditional sale rationale, see Vold, Cash Sales, 14 St. Lours L. Rev. 1, 9 (1928); Comment, 34 Iows L. REv. 371 (1948); Note, $28 \mathrm{Kx}$. L.J. 322, 327 (1940).

50. The argument is that although the parties did not contemplate a credit tratsaction, the seller actually extended credit. See cases cited in note 49 stipra. See also Note, 28 Ky. L.J. 322, 325 (1940). Of course, some time will always elapse between exchange of goods for a check and payment of the check by the bank. Proponents of the "cash sale" doctrine have met this difficulty by qualifying the non-credit requirement. Transfer of goods and payment must only be "substantially simultaneous." For discussion and cases, see Vold, Worthless Check Cash Sales, "Stubstantially Simultancous" and Conflicting Analogies, 1 Hastrngs Journal 111 (1951); Collins, Title to Goods Paid For with Worthless Check, 15 So. CALIF. L. Rev. 340, 343 n.22 (1942); Note, 28 KY. L.J. 322 n.3 (1940). Nevertheless, delivery and ultimate payment are not "actually" simultaneous, and 
and retains title to secure payment;" and unless the "cash sale" seller publicizes the transaction, he deserves no greater protection than the conditional seller who fails to record his rights. ${ }^{52}$ While this rationale would protect bona fide third parties ${ }^{53}$ in the face of a clear intent to retain title, application of the recording statutes is unrealistic. Acceptance of a check does not create the type of credit transaction contemplated by the recording statutes. Hence, a seller in the ordinary check transaction will never use a recording device. The conditional sale rationale thus seems like an unduly complicated way of avoiding the "cash sale" doctrine.

Estoppel is the most common defense. ${ }^{65}$ Following a traditional common law rule, courts generally hold the seller estopped if he is guilty of laches in pre-

the seller who accepts a check, in effect, relies on the buyer's creditworthiness. Note, 38 YALE L.J. 1154, 1155 (1929). Whether this can be called an extension of credit, therefore, is primarily a question of terminology. See note 54 infra.

51. See Comment, 34 Iows L. Rer. 371,373 (1945).

52. For use of this analogy to support the estoppel doctrine see note 62 inf fra.

53. The parties who are considered to be worth protscting under, e.g., a cunditional sale statute, do not necessarily coincide with those whose protection in non-ercdit transaetions seems desirable. Conditional sales statutes generally protect only purehesers for value and lien creditors. Uniforsr Condrtional Sales ACT $\$$ 5. Other third parties, sueh as brokers, would not be covered by such provisions and therefore be furced to bear the bad chel: loss. See De Vries r. Sig Ellingson \& Co., 100 F. Supp. 731 (D. Minn. 1951). Moresver, while some states have promoted conditional sales and other chattel security devices by protecting sellers without recording, WmuIstox, S.uLEs, Appendix C, Note to $\$ \mathbf{5}$, similar protection for sellers who accept worthless checks is not necessarily sound.

54. The common denominator of both transactions is, of course, that title ras\$age is conditioned on payment. See Note, 9 C.LIF. L. KEv. 78 (1921). And huw the yarties label the transaction is irrelevant. See, e.g.. N.Y. World Telegram Corp. v. MrGoldrick, 293 N.Y. 11, 80 N.E.2d 61 (1948) (transaction called "lease" held conditional sale). For

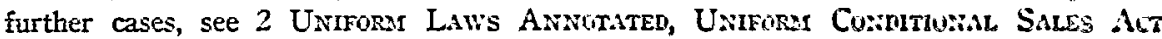
(1922), Cuns ANx. Pock. Part $\$ 1$, Case Notes (1951). However, the fact that the seller is not paid upon delivery does not necessarily mean he extended crcdit, as the term is commercially used. The recording statutes are drafted for transactions in which the parties contemplate and bargain for credit. But check payment, as such, is not a "credit" device by which the seller decreases the buyer's burden of maling payment, accopting in return such benefits as interest or additional orders. The check, as distinguished from a note, is primarily a mode of making a cash payment. See Hodgson v. Barrett, 33 Ohio St. 63, 31 Am. Rep. 527 (1877).

55. Estoppel is the only rationale by which, under the Sales Act, a third party may acquire rights from one who does not hold title. UNIFoss SALES ACr $\$ 23$. In bad chcel: cases, courts have sometimes based the estoppel defense on the seller's "misplaced confidence" or "negligence," Crescent Chevrolet Co. v. Lewis, 230 Iowa 1074, 300 N.W. 200 (1941); Michigan R.R. v. Phillips, 60 Ill. 190 (1S71). The majority of courts, however, follow the rule: if "one of two innocent persons must suffer by the act of a third, he who has enabled such third person to occasion the loss must sustain it." Liclibarrow v. Mlason, 2 Durn. \& East 63, 70 (1787). Cf. Sullivan Co. v. Larson, 149 Neb. 97, 30 N.IW.2d 460 (1948) ; Seward v. Evrard, 240 Mo. App. 893, 222 S.W.2d 509 (1949). The "he who" rule has been criticized as being applicable to both third party and seller with equal justification. See Vold, Warthless Check Cash Salcs. "Substantially Simullancous" and Conficting Analogics, 1 Hastings Jourana 111, 121 (19:0). 
senting the check ${ }^{56}$ or pursuing the goods, ${ }^{57}$ or if he transfers both possession of the goods and "indicia of ownership." 68 Almost any writing related to the sale now satisfies the "indicia" requirement, whether or not the document has any bearing on title to the transferred goods."50 Certainly, the "indicia" requirement is meaningless when the buyer is a merchant. ${ }^{60} \mathrm{~A}$ merchant's possession of the goods is sufficient to permit a bona fide third party to infer that the merchant is entitled to resell." Moreover, since "indicia" are no longer required for estoppel in other areas of sales law, ${ }^{62}$ the requirement in bad check cases is an exception to the modern rule. If the "indicia" requirement were dropped, estoppel would provide a simple device for protecting all bona fide third parties.

56. E.g., Pohl v. Johnson, 179 Minn. 398, 229 N.W. 555 (1930); Oldridge v. Sutton, 157 Mo. App. 485, 137 S.W. 994 (1911).

57. E.g., People's State Bank v. Brown, 80 Kan. 520, 103 Pac. 102 (1909); Frech v. Lewis, 218 Pa. 141, 67 Atl. 45 (1907). See also Vold, Cash Sales, 14 ST, Lours L. Rev. 1,7 nn.23, 24, 25 (1929).

58. See De Vries v. Sig Ellingson \& Co., 100 F. Supp. 781 (D. Minn. 1951); Clark v. Hamilton Diamond Co. 209 Cal. 1, 284 Pac. 915 (1930); Capital Automobile Co. v. Ward, 54 Ga. App. 873, 189 S.E. 713 (1936); Gustafson v. Equitable Loan Ass'n, 186 Minn. 236, 243 N.W. 106 (1932). The reason generally given to support the "indicia" requirement is that " $[0]$ ne may possess a chattel as a borrower, a bailee, lessee or under other varied circumstances ..." J. L. McLure Motor Co. v. McLain, 34 Ala. App. 614, 616, 42 So. 2d 266, 268 (1949). Cf. Cowan v. Thompson, 25 Tenn. App. 130, 152 S.W.2d 1036 (1941); Young v. Harris-Cortner, 152 Tenn. 15, 268 S.W. 125 (1924). This argument, however, is not convincing. While in a bailor-bailee transaction, the protection of the owner may be desirable, he need not necessarily be protected in the seller-buyer relationship, where his original intention was not to retain but to dispose of the goods.

Courts differ on the meaning of "indicia of ownership." It seems that generally some kind of document is required. See note 59 infra. But the more liberal view considers the term interchangeable with "circumstantial evidence." Blount v. Bainbridge, 79 Ga. App. 99, 53 S.E.2d 122 (1949).

59. E.g., White v. Pike, 240 Iowa 596, 36 N.W.2d 761 (1949) (certificate of title); Wolfe v. Smith, 80 Ga. App. 136, 55 S.E.2d 675 (1949) (bill of sale); Johnson-Brinkman Comm. Co. v. Central Bank of Kansas City, 116 Mo. 558, 22 S.W. 813 (1893) (bill of lading); Ammon v. Gamble-Robinson Comm. Co., 111 Minn. 452, 127 N.W. 448 (1910) (warehouse receipts); Sullivan v. Larson, 149 Neb. 97, 30 N.W.2d 460 (1948) (truck billing); Crescent Chevrolet Co. v. Lewis, 230 Iowa 1074, 300 N.W. 260 (1941) (invoice).

The requirement of documentary "indicia" is absurd when the document itself gives notice of the check payment. Yet some courts have protected third parties becallse of such documents. E.g., Crescent Chevrolet Co. v. Lewis, supra; Wolfe v. Smith, supra. Cf. Hall v. LeCroy, 79 Ga. App. 676, 54 S.E.2d 468 (1949).

60. Some courts do not require "indicia" when the buyer is a merchant. Capital Automobile v. Ward, 54 Ga. App. 873, 189 S.E. 713 (1936); Keegan v. Kaufman Bros,, 68 Cal. App. 2d 197, 156 P.2d 261 (1945). Cf. Boice v. Finance \& Guaranty Corp., 127 Va. 563, 102 S.E. 591 (1920). See Note, 80 U. of PA. L. REv. 755 (1932).

61. See, e.g., Uniforas Conditional Sales Acr $\$ 9$ (buyer in the ordinary course of business protected against the seller even if the contract was properly filed); UNIFORM TRUST Receipts ACt $\S 9$; UnIform Commerctal Code $\S 2-403$ (2) (Official Draft 1952) ; Williston, Sales $\$ 314$. See also Notes, 80 U. of PA. L. Rev. 755 (1932) ; 2 Rock $Y$ MT. L. REv. 261 (1930) ; 42 HARv. L. REv. 573 (1929).

62. E.g. Unifora Conditional Sales Act $\$ 5$; Uniform Trust Receipts Act $\$ \S$ $8,9$. 